\title{
What Do Managers Really Want?
}

\author{
J. K. Haberstok
}

Fluor Daniel Hanford, Inc.

Date Published

April 1997

To Be Published in

Journal for Quality and Participation

Prepared for the U.S. Department of Energy Assistant Secretary for Environmental Management

Project Hanford Management Contractor for the

U.S. Department of Energy under Contract DE-AC06-96RL13200

Copyright License By scceptance of this article, the publisher and/or recipient acknowledges the

U.S. Government's right to retain a nonexclusive, royalty-tree license in and to any copyright covering this paper.

Approved for public release; distribution is unlimited 
LEGAL DISCLAIMER

This report was prepared as an account of work sponsored by an agency of the United States Government. Neither the

United States Government nor any agency thereof, nor any of their employees, nor any of their contractors, subcontractors or their employees, makes any warranty, express or implied, or assumes any legal tiability or responsibility for the accuracy, completeness, or any third party's use or the results of such use of any information, apparatus, product, or process disclosed, or represents that its use would not infringe privately owned rights. Reference herein to any specific commercial product, process, or service by trade name, trademark, manufacturer, or otherwise, does not necessarily constitute or imply its endorsement, recommendation, or favoring by the United States Government or any agency thereof or its contractors or subcontractors. The views and opinions of authors expressed herein do not necessarily state or reflect those of the United States Government or any agency thereof.

This report has been reproduced from the best avalable copy.

Printed in the United States of America

DISCLM-2.CHP (1-91) 


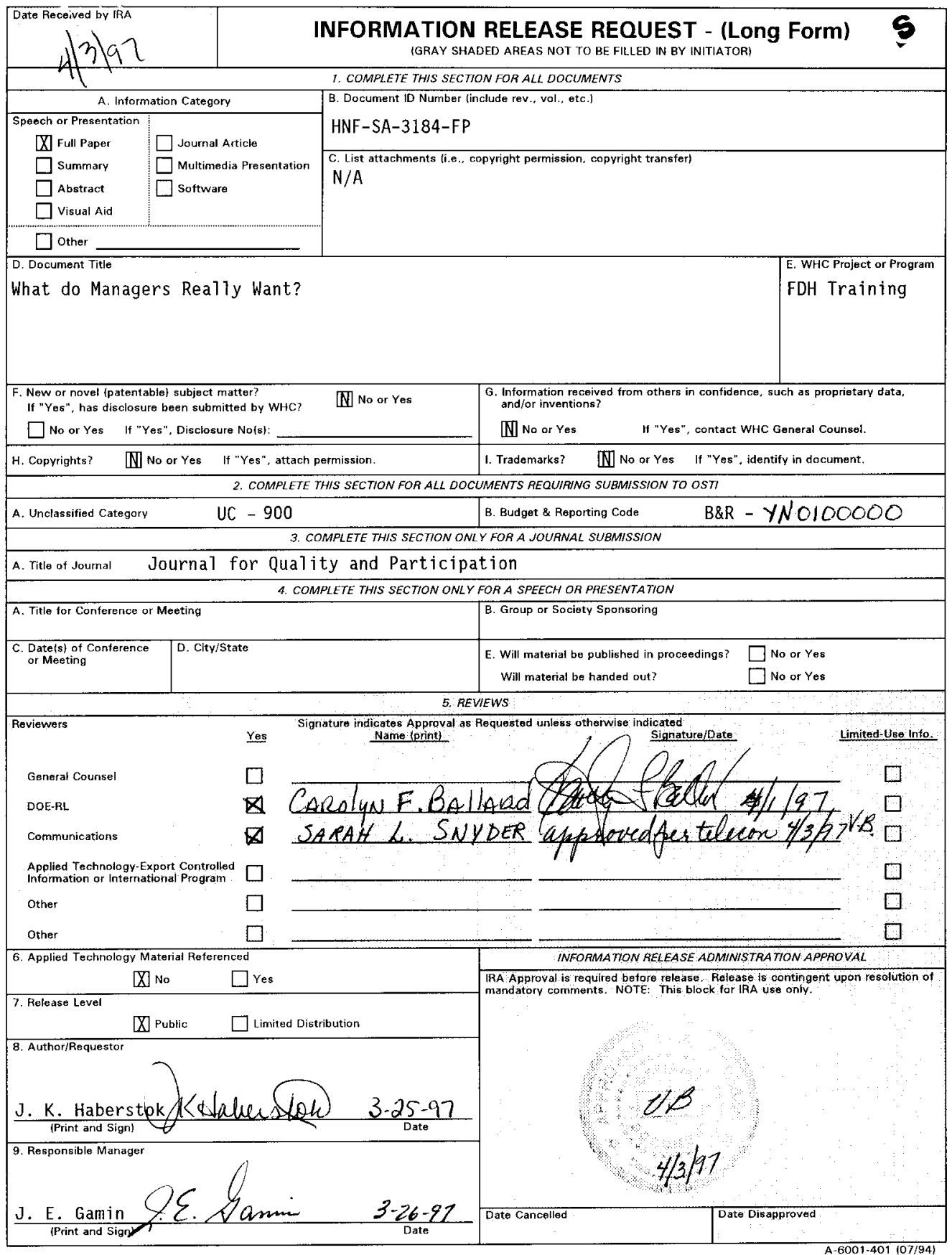


HNF-SA-3184-FP

Document ID Number

10. LEGENDS/NOTICES/MARKINGS (Required by WHC-CM-3-4 or Reviewer); Reviewer indicates applicable markings to be affixed or removed

Affix Remove Initlals

Applied Technology

Avaitability - OSTI

Availability - ESTSC

Availability - NTIS

Business-Sensitive Information

Computer Software Notice

Copyright License Notice

Export Controlled Information:

Legal Disclaimer

Limited Diselosure

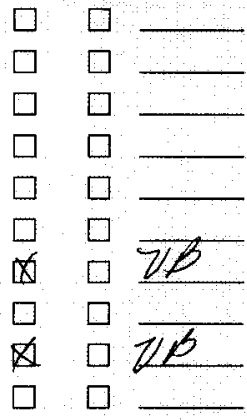

Affix Pemove Initials

Official Use Only

Patent Status

Predocisional Information

Programmatic Notice

Proprietary Information

Purpose and Use

Thesis/Dissertation

Trademsik Disclaimer.

Other:

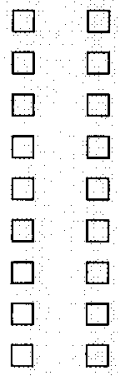

\section{MANDATORY COMMENTS (List only mandatary comments here All other comments shall be made on the dociument and returned to the author.)
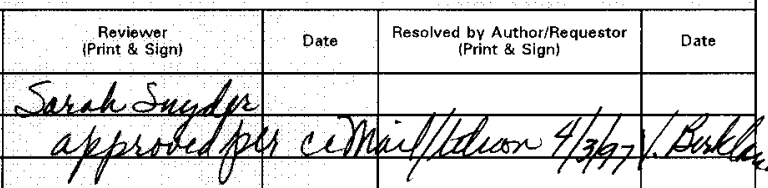

12. AODITIONAL INFORMATION/COMMENTS

Comments from Sarah were incorpotated. $4 / 3 / 92 \mathrm{~V}$. Disteland 


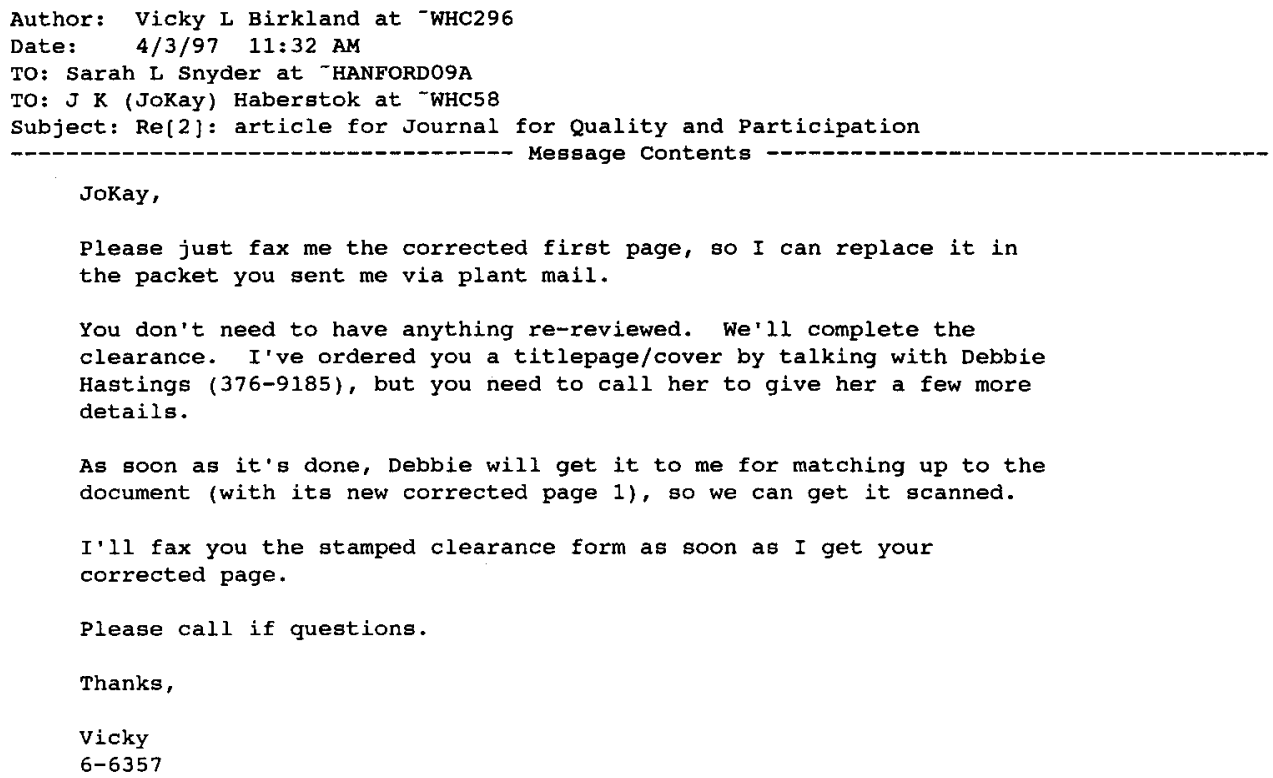


First, there are six, not seven, enterprise companies performing project work.

Second, FDH is the prime contract and there are 5 major subcontractors and DynCorp. (DynCorp, while it plays an important role, is not technically a major sub because it is not sharing in the mega-fee pool.) Despite possible perception, there is no primary subcontractor as described in your paper.

I would suggest that the simplest way to characterize the PHMC arrangement is simply to rewrite this sentence: "The central Training Organization within FDH provides cross-cutting training services for its own personnel as well as for six subcontractors and six enterprise companies performing project work across the 560 square miles of the Hanford site near Richland, Washington."

If you have any questions, please call.

sarah 
We asked, we listened, we even used their input...

\section{WHAT DO MANAGERS REALLY WANT?}

JoKay Haberstok -- Fluor Daniel Hanford, Inc

All good training organizations ask for customer feedback. But what they actually do with the feedback is what really counts.

Fluor Daniel Hanford, Inc. (FDH) is the Management Contractor for the Project Hanford Management Contract for the Department of Energy - Richland Operations Office. The Central Training

Organization within FDH provides cross-cutting training services for its own personnel as well as for six subcontractors and six enterprise companies performing project work across the 560 square miles of the Hanford Site near Richland, Washington.

Manager Safety Training has been presented by the Environmental, Safety and Health Training (ES\&HT) team to managers, supervisors, team leads, and other personnel across the Hanford Site for over four years. The training is intended to heighten the awareness of management toward both identified (via accident/injury reports) and potential safety issues and concerns. Managers need to be aware of their responsibilities and to know where to go/who to contact (for example, company manuals or facility safety representatives) for additional information. At the conclusion of each training session, students are asked to complete a Level I evaluation (Kirkpatrick Model, see sidebar) and this feedback is reviewed by the instructors. Commonly, revisions to the course content and presentation format are made solely by the ES\&HT instructors and their manager each year.

In 1996, that approach to training evaluations and course revisions began to change. When revising the course, the instructional team updated the Level I instrument to specifically ask some open-ended questions, including:

$\square \quad$ How would you improve this training?

$\square \quad$ What topics/issues do you feel would most benefit you in managing safety?

In October of 1996, ES\&HT embarked on a Level III evaluation of Manager Safety Training. The purpose of a Level III is to determine the degree to which students transfer course objectives and the training received into workplace performance. Working with the Hanford Training Assessment Center (HTAC), an internal FDH Training team that assists in the development and conduct of training evaluations, a task team comprised of two ES\&HT team members and an HTAC consultant was formed. With the involvement and concurrence of the ES\&HT manager, the team determined purposes for conducting this Level III evaluation:

To determine whether Manager Safety Training is effective To identify the best approach to use for updating this training each year To determine what the focus of this training should be in 1997. 
To answer these and other important questions, the team designed a survey, which included ten questions and encouraged write-in comments as well. A letter was sent from the ES\&HT manager to the managers to inform them of the evaluation purpose and to encourage their participation. Surveys were sent to a randomly selected sampling of 100 students who had completed Manager Safety Training between March 1 and September 30, 1996. Of those, 55 forms were completed, returned and analyzed as part of the Level III process. In addition, the Level I student feedback forms from classes during the selected time frame were reviewed.

Following initial analysis of the survey results, the team conducted telephone interviews with 25 of the students who had indicated their willingness to participate in a follow-on interview. These interviews, while time consuming (trying to schedule 15 minutes to talk with busy managers is no easy feat!) provided valuable additional information and insight into what they personally felt should be emphasized in the 1997 Manager Safety Training course.

In December, a facilitated focus group meeting was held with five managers from various areas of the Hanford site. These managers were ones who had also indicated on the surveys that they would be willing to spend four to eight hours of their time to help determine the content and format of the 1997 training. This group brainstormed ideas for the format and table-top (hands-on) exercises for the course

From there, armed with the Level III final report and copious telephone and meeting notes, the ES\&HT team designed the Manager Safety Training course which is now being presented.

The previous year's training had focused on accident investigation and case management -- in other words, how to respond or react when an accident or injury occurs. From the Level III evaluation, it was determined that most managers felt that it would be more beneficial to focus on being PROACTIVE when it comes to safety.

\section{The recommendation was that the 1997 training course should...}

FIRST, provide the "foundation" for safety. Managers need to be aware of the company procedures, policies and programs that they are responsible to follow and implement in the workplace.

SECOND, provide tools for safety success. With the foundation in place, managers need tools in order to effectively build on that foundation. Managers need ideas to help them implement good communications, teamwork and a team spirit of looking out for each other when it comes to safety. They need to understand how to perform comprehensive pre-job safety meetings with their team. They need ideas for interesting safety meetings.

With a good foundation and the right tools and materials, managers can be successful in reaching their safety goals. There are company safety goals, and most work teams have set their own internal safety goals as well -- such as reducing or eliminating injuries/accidents, or simply increasing everyone's awareness of safety requirements and how to meet those requirements

The 1997 Manager Safety Training follows the same format as the company's primary safety procedure manuals, and will be updated as changes occur in the policies and procedures. The student handout 
includes highlights from these manuals as well as copies of many of the forms that are used regularly in the workplace. The handout also includes reference information, including a listing of the company's industrial safety/industrial hygiene points of contact, examples of workplace housekeeping and safety inspection checklists, and directions for accessing safety "lessons learned" from the company's internal web site. In addition, photos taken at actual worksite locations are used for identification of both positive examples ("What's right with this picture?" Would you take the time to recognize a team member in this area for working safely?") and areas needing improvement ("Do you see any potential safety hazards here?" What would you do if you came across this situation?").

Another change to the 1997 course is the addition of a pre-test. Because manager's responsibilities for safety are so important, at the beginning of the training session students are asked to complete a 40 question, mostly multiple choice, pre-test. The questions and answers are then discussed as part of the overall learning experience. While some managers are initially taken aback at being required to "take a test," almost all agree that this has helped them to realize that they don't know all the answers. The average number of missed questions on the pre-test is 11 . "I was surprised at the answers to some of the questions that I really thought I knew," said one student. "The test showed me that I should pay attention and actively participate in the rest of the course."

ES\&HT has received positive feedback from managers completing the 1997 Manager Safety Training. (All students are asked to complete a Level 1 evaluation form at the completion of each training session, and the instructors explain to students at the beginning of the course why the team asks for their feedback and how it is reviewed and used to make improvements in future sessions.)

Comments from some of the managers who participated in the telephone interviews and the focus group meeting have made the results of the Level III worthwhile to all involved: "I was happy to make the time to be involved in this. And I'm thrilled to see that my ideas were actually listened to and incorporated into this year's training!" 
(Possible "sidebars" to this article)

\section{LEVELS OF EVALUATION}

The basic elements of the Kirkpatrick Model form the core of the FDH Training evaluation process by providing guidelines for measuring trainee reaction, learning, performance, improvement and organizational impact.

\section{LEVEL I = Reaction}

Measures students' satisfaction levels with (reaction to) training. Did they like the training?

\section{LEVEL II = Learning}

Measures how much students learned using written, oral and/or performance tests. How well did they learn it?

\section{LEVEL III = Behavior}

Measures the extent to which students use on the job what they learned in training. Did they use it back on the job?

\section{LEVEL IV = Results}

Tracks, calculate and compares the costs and benefits of training (cost-benefit analysis).

Did it produce a return on investment?

\section{SURVEY SAYS...}

The following is a sampling of survey questions and responses:

Do you believe a structured Manager Safety Training Program of some type is needed?

$$
\text { Yes }-79.6 \% \quad N o-20.4 \%
$$

Do you believe some type of anmal or follow-on training is needed once a manager complete the initial Manager Safety Training?

$$
\text { Yes }-72.7 \% \quad \text { No }-27.3 \%
$$

Topics most recommended for inclusion in Managers' Safety Training 1997:

$\checkmark \quad$ Management Responsibilities

$\checkmark \quad$ Hazards Recognition/Awareness

\section{SOME FEEDBACK/COMMENTS FROM STUDENTS UPON COMPLETION OF THE 1997 COURSE}

"Class was fun and also increased my awareness of responsibilities toward the work place, employees, and myself"

"Beneficial lessons learned were passed on during the class"

"Good discussions"

"Quiz is a good interest-generating device"

"Interesting class; much improved!" 


\section{Biographical Information}

JoKay Haberstok is a Senior Training Specialist with Fluor Daniel Hanford, Inc. In her current role with the ES\&HT team, she designed and administers an instructor observation process, performs internal self-assessments, and assists with course evaluations and revisions. Past experience includes marketing and public relations, and total quality training and facilitation. Her articles on team building, communications and recognition have been published in the AQP Report. A charter member and past secretary of the AQP "Quest for Quality" chapter in Richland, Washington, JoKay was the recipient of the Judy Gibson Volunteer Award for outstanding contributions to the AQP in 1996. 